\title{
Herbidospora yilanensis sp. nov. and Herbidospora daliensis sp. nov., from sediment
}

\author{
Correspondence \\ M. Tseng \\ tjm@firdi.org.tw
}

\author{
M. Tseng, S.-F. Yang and G.-F. Yuan
}

Bio-resource Collection and Research Center, Food Industry Research and Development Institute, HsinChu, 300, Taiwan

\begin{abstract}
Two actinomycete strains, $0351 \mathrm{M}-12^{\top}$ and $0385 \mathrm{M}-1^{\top}$, were isolated from sediment samples collected from Yilan County and Dali City in Taiwan, respectively. The two isolates displayed characteristics which were similar to those of the genus Herbidospora. They both produced branched and unfragmented substrate mycelia, and aerial hyphae were not produced on Bennett's, glucose-asparagine, Hickey-Tresner, sucrose-nitrate, yeast extract-malt extract, or inorganic salts-starch agars. Short spore-chains were borne on the tips of sporophores arising from the substrate mycelia on oatmeal and oatmeal-nitrate agars. The spore chains contained 10-20 non-motile, smooth-surfaced, oval spores. Galactose, glucose, mannose and madurose were the whole-cell sugars in both strains and meso-diaminopimelic acid was present in their peptidoglycans. The phospholipid pattern was PIV. The predominant menaquinone was MK-10 $\left(\mathrm{H}_{4}\right)$ in both strains. Mycolic acids were not detected. Major cellular fatty acids were iso- $\mathrm{C}_{16: 0}$ and 10-methyl $\mathrm{C}_{17: 0}$. The DNA G+C contents of the two new isolates were $70.6 \mathrm{~mol} \%\left(0351 \mathrm{M}-12^{\top}\right)$ and $70.7 \mathrm{~mol} \%\left(0385 \mathrm{M}-1^{\top}\right)$, respectively. The relatedness between the isolates and Herbidospora cretacea NBRC $15474^{\top}$ was $40.7-48.5 \%$. The value of DNA-DNA hybridization between strain $0351 \mathrm{M}-12^{\top}$ and strain $0385 \mathrm{M}-1^{\top}$ was $53.6-54.9 \%$. These two isolates could also be distinguished from each other and from $H$. cretacea NBRC $15474^{\top}$ by differences in several phenotypic characteristics. We therefore propose the names Herbidospora yilanensis sp. nov. and Herbidospora daliensis sp. nov. for these novel bacteria, with strains $0351 \mathrm{M}-12^{\top}\left(=\right.$ FIRDI $003^{\top}=$ BCRC $16875^{\top}={\left.\text { LMG } 24337^{\top}\right) \text { and } 0385 \mathrm{M}-1^{\top}(=\text { FIRDI 004 }}^{\top}$ $=$ BCRC $16876^{\top}=$ LMG $24336^{\top}$ ) as the type strains, respectively.
\end{abstract}

The genus Herbidospora was described by Kudo et al. (1993) and contains only one species, Herbidospora cretacea, at the time of writing. $H$. cretacea produces branching substrate mycelia, but no distinct aerial hyphae. Short chains of spores (10-30 spores per chain) are borne on the tips of sporophores arising directly from the agar surface. The isomer of diaminopimelic acid $\left(\mathrm{A}_{2} \mathrm{pm}\right)$ is the meso isomer. The whole-cell sugars are glucose, mannose, ribose and a trace amount of madurose. The acyl type of muramic acid in the cell wall is the acetyl type. The phospholipid pattern is the type PIV pattern of Lechevalier et al. (1977). The major fatty acids are straight, iso-

Abbreviations: $\mathrm{A}_{2} \mathrm{pm}$, diaminopimelic acid; GlcNU, a phospholipid of unknown structure containing glucosamine; $\mathrm{PE}$, phosphatidylethanolamine; PME, phosphatidyl- $\mathrm{N}$-monomethylethanolamine.

The GenBank/EMBL/DDBJ accession numbers for the $16 \mathrm{~S}$ rRNA gene sequences of strains $0351 \mathrm{M}-12^{\top}$ and $0385 \mathrm{M}-1^{\top}$ are DQ246623 and AY749433, respectively.

Tables showing cultural characteristics of strains $0351 \mathrm{M}-12^{\top}$ and $0385 \mathrm{M}-1^{\top}$, fatty acid methyl ester profiles and levels of DNA relatedness among isolates $0351 \mathrm{M}-12^{\top}, 0385 \mathrm{M}-1^{\top}$ and $H$. cretacea NBRC $15474^{\top}$ are available with the online version of this paper. branched, 10-methyl, and 2-hydroxyl acids. Mycolic acids are absent. The predominant menaquinone is $\mathrm{MK}-10\left(\mathrm{H}_{4}\right)$; small amounts of $\mathrm{MK}-10\left(\mathrm{H}_{6}\right), \mathrm{MK}-10\left(\mathrm{H}_{2}\right), \mathrm{MK}-10\left(\mathrm{H}_{0}\right)$ and $\mathrm{MK}-9\left(\mathrm{H}_{4}\right)$ are also present. The $\mathrm{G}+\mathrm{C}$ content of the genomic DNA is 69-71 mol\%.

During our search for novel actinomycetes, we isolated some novel strains from sediments in Taiwan. In this study, we describe two isolates, $0351 \mathrm{M}-12^{\mathrm{T}}$ and $0385 \mathrm{M}-1^{\mathrm{T}}$, belonging to the genus Herbidospora. On the basis of polyphasic taxonomic characterization that combined phenotypic properties, phylogenetic and genetic data, we propose that the two strains should be classified as novel species of genus Herbidospora as Herbidospora yilanensis sp. nov. and Herbidospora daliensis sp. nov.

Strains $0351 \mathrm{M}-12^{\mathrm{T}}$ and $0385 \mathrm{M}-1^{\mathrm{T}}$ were isolated from sediment samples from a dry lake in Yilan county and a river in Dali city in Taiwan, respectively. The wet clay sediment samples were dried at room temperature for 7 days. Approximately $2 \mathrm{~g}$ of each sediment sample was suspended in $18 \mathrm{ml}$ of sterile distilled water, subjected to shaking for $1 \mathrm{~h}$ and allowed to settle. The suspensions $(100 \mu \mathrm{l})$ were plated on humic acid-vitamin (HV) agar 
(Hayakawa \& Nonomura, 1987) supplemented with cycloheximide $\left(50 \mathrm{mg} \mathrm{l}^{-1}\right)$ and nalidixic acid $\left(20 \mathrm{mg} \mathrm{l}^{-1}\right)$ and incubated at $28{ }^{\circ} \mathrm{C}$ for 4 weeks. The two strains were purified and maintained on oatmeal agar slants and as suspensions of spores or mycelial fragments in glycerol $(20 \%, \mathrm{v} / \mathrm{v})$ stored at $-20{ }^{\circ} \mathrm{C}$.

Morphological characteristics of the two strains were observed by scanning electron microscopy (S-4700, Hitachi) following incubation on oatmeal agar for 14 days at $28{ }^{\circ} \mathrm{C}$ and fixation in $4 \%$ osmium tetraoxide solution. The samples were then dehydrated through a series of ethanol-acetone solutions and critical point dried. Cultural characteristics were tested by using 21-day-old cultures grown at $28{ }^{\circ} \mathrm{C}$ on various media (Supplementary Table S1 available in IJSEM Online). The ISCC-NBS Colour-Name Charts (Kelly, 1964) were used for determining colour designations of the substrate mycelium. Media and procedures used for determination of physiological and biochemical features and carbon source utilization were those described by Shirling \& Gottlieb (1966), Goodfellow (1971) and Gordon et al. (1974).

The isomer of $\mathrm{A}_{2} \mathrm{pm}$ and the sugars in whole-cell hydrolysates were determined by the methods of Hasegawa et al. (1983). The presence of mycolic acids was examined by TLC following Minnikin et al. (1975), and phospholipids were extracted and identified following the method of Minnikin et al. (1984). Menaquinones were extracted and purified by the method of Collins et al. (1977), then analysed by HPLC (model 600, Waters) using a Nova-Pak C18 column. The cellular fatty acid compositions of strains $0351 \mathrm{M}-12^{\mathrm{T}}$ and $0385 \mathrm{M}-1^{\mathrm{T}}$ were determined by using the Sherlock Microbial Identification System (MIDI). Extracts of the methylated fatty acids were prepared according to the protocol provided by the manufacturer and analysed with a 5890 gas chromatograph equipped with a flame-ionization detector and an automatic injector with a G1512A controller (Hewlett Packard). Identification of the peaks was made by comparing the results with the built-in TSBA 40 database (MIDI).

Total DNA was extracted from 14-day-old cells by using the Qiagen genomic DNA kit. The $\mathrm{G}+\mathrm{C}$ content of the DNA was determined by the HPLC method of Tamaoka \& Komagata (1984). The 16S rRNA gene was PCR-amplified by using the method of Nakajima et al. (1999) and was sequenced directly on an ABI model 3730 automatic DNA sequencer by using a PRISM ready reaction dye primer cycle sequencing kit (Applied Biosystems). Phylogenetic analysis was performed using the software packages PHYLIP (Felsenstein, 1993) and MEGA version 2.1 (Kumar et al., 2001) after multiple alignment of the sequences by CLUSTAL_X (Thompson et al., 1997). Genetic distances were calculated using the Kimura two-parameter model (Kimura, 1980, 1983) and clustering was performed by using the neighbour-joining method (Saitou \& Nei, 1987). Bootstrap analysis was used to evaluate the tree topology of the neighbour-joining data by performing 1000 resamplings (Felsenstein, 1985).

Strains $0351 \mathrm{M}-12^{\mathrm{T}}$ and $0385 \mathrm{M}-1^{\mathrm{T}}$ produced branched and unfragmented substrate mycelia; no distinct aerial hyphae were found. Short spore chains were borne on the tips of sporophores arising from the substrate mycelia. The spore chains were composed of 10-20 non-motile, smoothsurfaced, oval spores. Scanning electron micrographs of strains $0351 \mathrm{M}-12^{\mathrm{T}}$ and $0385 \mathrm{M}-1^{\mathrm{T}}$ are shown in Fig. 1 and Fig. 2. The cultural characteristics of strains $0351 \mathrm{M}-12^{\mathrm{T}}$ and $0385 \mathrm{M}-1^{\mathrm{T}}$ are shown in Supplementary Table S1. Growth was good on most of the media tested and the substrate mycelia on most media were yellow. Sporulation occurred on oatmeal-nitrate, yeast-extract-starch (only strain $0351 \mathrm{M}-12^{\mathrm{T}}$ ), oatmeal, inorganic salts-starch (only strain $0385 \mathrm{M}-1^{\mathrm{T}}$ ) and glycerol-asparagine (only strain $0351 \mathrm{M}-12^{\mathrm{T}}$ ) agars. No soluble pigments were produced on any of the media tested. The results of the physiological and biochemical tests are indicated in Table 1 and in the species descriptions.

Strains $0351 \mathrm{M}-12^{\mathrm{T}}$ and $0385 \mathrm{M}-1^{\mathrm{T}}$ contained glucose, galactose, mannose, ribose and a trace amount of madurose in whole-cell hydrolysates, and the cell-wall peptidoglycan contained meso- $\mathrm{A}_{2} \mathrm{pm}$. The predominant menaquinone was $\mathrm{MK}-10\left(\mathrm{H}_{4}\right)$ and minor components were MK-10 $\left(\mathrm{H}_{6}\right)$ and MK-9 $\left(\mathrm{H}_{4}\right)$. Mycolic acids were not detected. The phospholipids were phosphatidylethanolamine (PE), phosphatidyl- $N$-monomethylethanolamine (PME) and a phospholipid of unknown structure containing glucosamine (GlcNU) (phospholipid type PIV of Lechevalier et al., 1977). The fatty acid methyl ester profiles of strains $0351 \mathrm{M}-12^{\mathrm{T}}$ and $0385 \mathrm{M}-1^{\mathrm{T}}$ are shown in Supplementary Table S2. The $\mathrm{G}+\mathrm{C}$ contents of the genomic DNA were 70.6 and $70.7 \mathrm{~mol} \%$, respectively.

The almost-complete 16S rRNA gene sequences of strains $0351 \mathrm{M}-12^{\mathrm{T}}(1517 \mathrm{nt})$ and $0385 \mathrm{M}-1^{\mathrm{T}}(1515 \mathrm{nt})$ were determined. Preliminary comparison of the sequences against

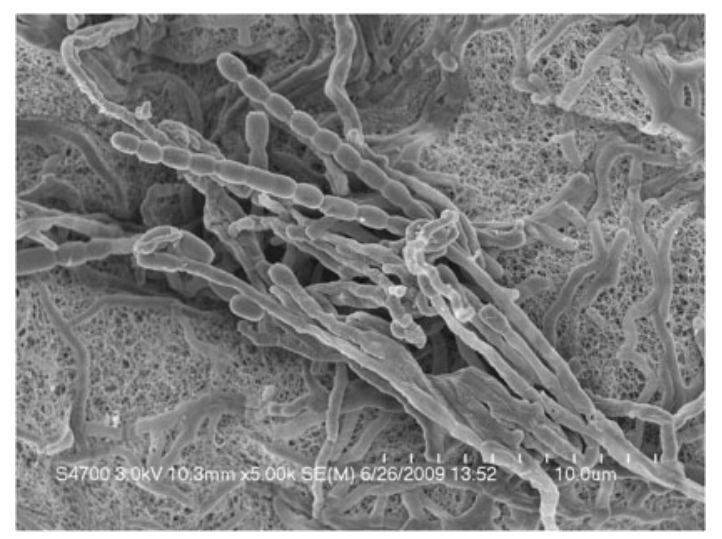

Fig. 1. Scanning electron micrograph of strain $0351 \mathrm{M}-12^{\top}$ after growth on oatmeal agar at $28{ }^{\circ} \mathrm{C}$ for 14 days. Bar, $10 \mu \mathrm{m}$ 


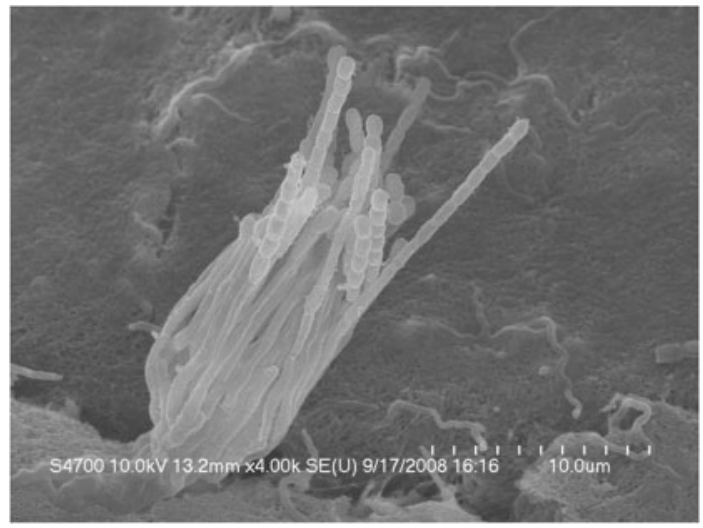

Fig. 2. Scanning electron micrograph of strain $0385 \mathrm{M}-1^{\top}$ after growth on oatmeal agar at $28{ }^{\circ} \mathrm{C}$ for 14 days. Bar, $10 \mu \mathrm{m}$

the GenBank database indicated that the two isolates belonged to the family Streptosporangiaceae (Fig. 3) and were most closely related to $H$. cretacea NBRC $15474^{\mathrm{T}}$. The binary similarities of the two isolates to $H$. cretacea were $98 \%$. The results of DNA-DNA hybridization among isolates $0351 \mathrm{M}-12^{\mathrm{T}}, 0385 \mathrm{M}-1^{\mathrm{T}}$ and $H$. cretacea NBRC $15474^{\mathrm{T}}$ are shown in Supplementary Table S3. The relatedness between the isolates and $H$. cretacea NBRC $15474^{\mathrm{T}}$ was $40.7-48.5 \%$. The value of DNA-DNA

Table 1. Phenotypic properties useful for distinguishing strains $0351 \mathrm{M}-12^{\top}$ and $0385 \mathrm{M}-1^{\top}$ from $H$. cretacea NBRC $15474^{\top}$

Strains: $1,0351 \mathrm{M}-12^{\mathrm{T}} ; 2,0385 \mathrm{M}-1^{\mathrm{T}} ; 3$, H. cretacea $\mathrm{NBRC} 15474^{\mathrm{T}} .+$, Positive; - , negative.

\begin{tabular}{|lccc|}
\hline Characteristic & $\mathbf{1}$ & $\mathbf{2}$ & $\mathbf{3}$ \\
\hline Decomposition of: & & & \\
$\quad$ Hypoxanthine & - & - & + \\
Aesculin & - & - & + \\
Carbon source utilization & & & \\
L-Arabinose & - & + & - \\
Glycerol & + & - & + \\
myo-Inositol & + & - & - \\
Mannose & + & - & - \\
Melibiose & + & - & + \\
Salicin & + & - & + \\
Trehalose & + & - & - \\
Requirement for: & & & \\
Riboflavin & + & - & + \\
Thiamine & + & - & + \\
Organic acid utilization & & & \\
Fumaric acid & + & - & - \\
DL-Lactic acid & + & - & - \\
Mucic acid & - & - & + \\
Succinic acid & + & - & - \\
NaCl tolerance (\%) & 1 & 5 & 1 \\
& & & \\
\hline
\end{tabular}

hybridization between strain $0351 \mathrm{M}-12^{\mathrm{T}}$ and strain $0385 \mathrm{M}-1^{\mathrm{T}}$ was $53.6-54.9 \%$.

The DNA-DNA relatedness values of the isolates to each other and to the type strain of $H$. cretacea were lower than $70 \%$, which is the recommended threshold value for the delineation of genomic species (Wayne et al., 1987). The physiological characteristics also showed (Table 1) that the isolates were distinguishable from $H$. cretacea NBRC $15474^{\mathrm{T}}$. Therefore, we propose that the isolates represent novel species of the genus Herbidospora, for which we propose the names Herbidospora yilanensis sp. nov. and Herbidospora daliensis sp. nov.

\section{Description of Herbidospora yilanensis sp. nov.}

Herbidospora yilanensis (yi.lan.en'sis. N.L. fem. adj. yilanensis pertaining to Yilan county, Taiwan, where the micro-organism was isolated).

Cells are Gram-positive, aerobic, non-acid-fast and mesophilic. Produces branched and unfragmented substrate mycelia; no aerial hyphae are found. Short sporechains are borne on the tips of sporophores arising from the substrate mycelium. Spore chains are composed of 10-20 non-motile, smooth-surfaced, oval spores. The substrate mycelium is yellowish white to yellow. No soluble pigments are produced. Good growth occurs on most media, but sporulation only occurs on oatmeal-nitrate, yeast-extract-starch, oatmeal and glycerol-asparagine agars. Growth occurs between 20 and $40{ }^{\circ} \mathrm{C}$; $\mathrm{NaCl}$ tolerance is $1 \%$ on nutrient agar. Decomposes starch but not adenine, aesculin, hypoxanthine, tyrosine or xanthine. Fructose, fumaric acid, galactose, glucose, glycerol, DLlactic acid, myo-inositol, maltose, mannitol, mannose, melibiose, melezitose, raffinose, rhamnose, salicin, sucrose, succinic acid and trehalose are utilized. Adonitol, Larabinose, benzoic acid, cellobiose, cellulose, dulcitol, erythritol, L-malic acid, mucic acid, propionic acid, Dribose, D-sorbitol, L-tartaric acid and xylose are not utilized. $p$-Aminobenzoic acid, myo-inositol and thiamine are required for growth. Biotin, nicotinic acid, pantothenic acid and pyridoxine are not required for growth. Melanin is not produced. Lysozyme sensitive. Glucose, galactose, mannose, ribose and a trace amount of madurose occur in whole-cell hydrolysates. The cell-wall peptidoglycan contains meso- $\mathrm{A}_{2} \mathrm{pm}$. The predominant menaquinone is MK$10\left(\mathrm{H}_{4}\right)$ and the minor components are MK-10 $\left(\mathrm{H}_{6}\right)$ and MK-9 $\left(\mathrm{H}_{4}\right)$. The phospholipids are PE, PME and GlcNU. The cellular fatty acid profile contains 10-methyl $\mathrm{C}_{17: 0}$ (41.94\%), iso- $\mathrm{C}_{16: 0}(18.44 \%), \mathrm{C}_{17: 1} \omega 8 c(6.34 \%), \mathrm{C}_{17: 0}$ $(4.47 \%), \mathrm{C}_{15: 0} \quad 2-\mathrm{OH} \quad(4.39 \%), \mathrm{C}_{16: 0} \quad(3.88 \%)$ and $\mathrm{C}_{17: 1} \omega 6 c(3.83 \%)$. The DNA G $+\mathrm{C}$ content of the type strain is $70.6 \%$.

The type strain is $0351 \mathrm{M}-12^{\mathrm{T}}\left(=\right.$ FIRDI $003^{\mathrm{T}}=\mathrm{BCRC}$ $16875^{\mathrm{T}}=\mathrm{LMG} 24337^{\mathrm{T}}$ ), which was isolated from sediment from Yilan, a county in the north of Taiwan. 


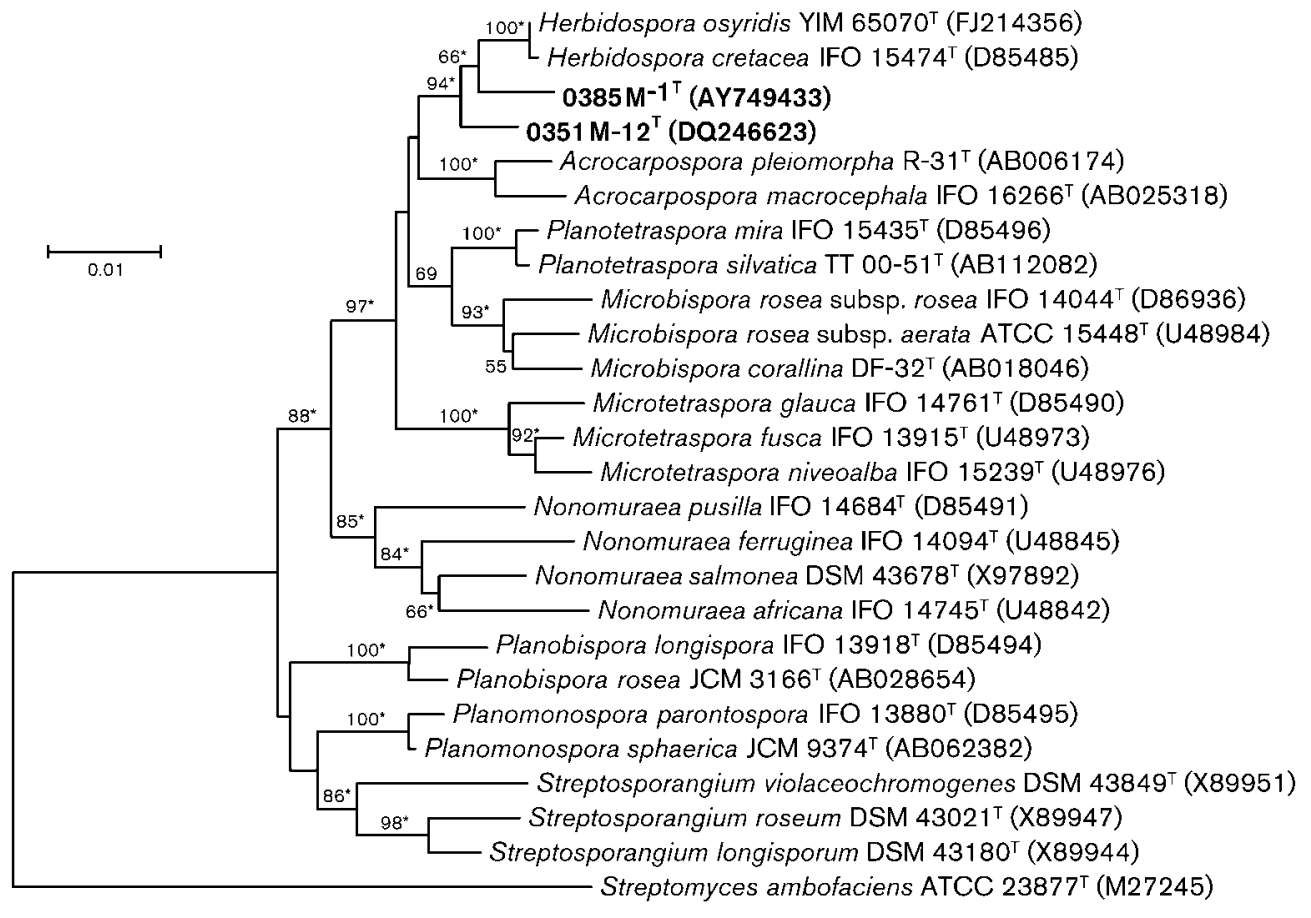

Fig. 3. Neighbour-joining tree based on almost complete 16S rRNA gene sequences showing the phylogenetic position of strains $0351 \mathrm{M}-12^{\top}$ and $0385 \mathrm{M}-1^{\top}$ among species of the family Streptosporangiaceae. Numbers at nodes indicate percentage of 1000 bootstrap resamplings and only values over $50 \%$ are given. Asterisks indicate branches of the tree that were also found using the maximum-parsimony (Kluge \& Farris, 1969) algorithm. Bar, 0.01 substitutions per nucleotide position.

\section{Description of Herbidospora daliensis sp. nov.}

Herbidospora daliensis (da.li.en'sis. N.L. fem. adj. daliensis pertaining to Dali city, Taiwan, where the micro-organism was isolated).

Cells are Gram-positive, aerobic, non-acid-fast and mesophilic. Produces branched and unfragmented substrate mycelia; no aerial hyphae are found. Short spore-chains are borne on the tips of sporophores arising from the substrate mycelium. The spore chains are composed of 10-20 nonmotile, smooth-surfaced, oval spores. Growth occurs between 20 and $40{ }^{\circ} \mathrm{C} ; \mathrm{NaCl}$ tolerance is $5 \%$ on nutrient agar. Decomposes starch but not adenine, hypoxanthine, tyrosine or xanthine. L-Arabinose, fructose, galactose, glucose, maltose, mannitol, melezitose, raffinose, rhamnose and sucrose are utilized. Adonitol, benzoic acid, cellobiose, cellulose, dulcitol, erythritol, fumaric acid, glycerol, myoinositol, DL-lactic acid, L-malic acid, mannose, melibiose, mucic acid, propionic acid, D-ribose, salicin, D-sorbitol, succinic acid, L-tartaric acid, trehalose and xylose are not utilized. Requires $p$-aminobenzoic acid and myo-inositol for growth. Biotin, nicotinic acid, pantothenic acid, pyridoxine, riboflavin and thiamine are not required for growth. Melanin is not produced. Lysozyme sensitive. Glucose, galactose, mannose, ribose and a trace amount of madurose occur in whole-cell hydrolysates. The cell-wall peptidoglycan contains meso- $\mathrm{A}_{2} \mathrm{pm}$. The predominant menaquinone is $\mathrm{MK}-10\left(\mathrm{H}_{4}\right)$ and the minor components are MK-10 $\left(\mathrm{H}_{6}\right)$ and MK-9 $\left(\mathrm{H}_{4}\right)$. The phospholipids are PE, PME and GlcNU. The cellular fatty acid profile contains 10-methyl $\mathrm{C}_{17: 0}(36.28 \%), \mathrm{C}_{17: 1} \omega 8 c(16.09 \%)$, iso $\mathrm{C}_{16: 0}$ (10.83\%), $\mathrm{C}_{17: 0}(9.21 \%), \mathrm{C}_{15: 0} 2-\mathrm{OH}(6.66 \%), \mathrm{C}_{17: 1} \omega 6 c$ $(3.63 \%)$ and $\mathrm{C}_{16: 0}(3.03 \%)$. The DNA G $+\mathrm{C}$ content of the type strain is $70.7 \%$.

The type strain is $0385 \mathrm{M}-1^{\mathrm{T}}\left(=\right.$ FIRDI $004^{\mathrm{T}}=\mathrm{BCRC}$ $16876^{\mathrm{T}}=\mathrm{LMG} 24336^{\mathrm{T}}$ ), which was isolated from sediment from central Taiwan.

\section{Acknowledgements}

This research was supported partially by the Ministry of Economic Affairs (project no. 93-EC-17-A-17-R7-0525). We thank Mr J. H. Chiou and Dr S. Y. Hsieh for assistance with sample collection. We also thank Dr Wen-Jun Li for correcting this manuscript.

\section{References}

Collins, M. D., Pirouz, T., Goodfellow, M. \& Minnikin, D. E. (1977). Distribution of menaquinones in actinomycetes and corynebacteria. J Gen Microbiol 100, 221-230.

Felsenstein, J. (1985). Confidence limits on phylogenies: an approach using the bootstrap. Evolution 39, 783-791.

Felsenstein, J. (1993). PHYLIP (phylogeny inference package), version 3.5c. Distributed by the author. Department of Genome Sciences, University of Washington, Seattle, USA. 
Goodfellow, M. (1971). Numerical taxonomy of some nocardio-form bacteria. J Gen Microbiol 69, 33-80.

Gordon, R. E., Barnett, D. A., Handerhan, J. E. \& Pang, C. H.-N. (1974). Nocardia coeliaca, Nocardia autotrophica, and the nocardin strain. Int J Syst Bacteriol 24, 54-63.

Hasegawa, T., Takizawa, M. \& Tanida, S. (1983). A rapid analysis for chemical grouping of aerobic actinomycetes. J Gen Appl Microbiol 29, 319-322.

Hayakawa, M. \& Nonomura, H. (1987). Humic acid-vitamin agar, a new medium for selective isolation of soil actinomycetes. J Ferment Technol 65, 501-509.

Kelly, K. L. (1964). Inter-Society Color Council - National Bureau of Standards Color Name Charts Illustrated with Centroid Colors. Washington, DC: US Government Printing Office.

Kimura, M. (1980). A simple method for estimating evolutionary rates of base substitutions through comparative studies of nucleotide sequence. J Mol Evol 16, 111-120.

Kimura, M. (1983). The Neutral Theory of Molecular Evolution. Cambridge: Cambridge University Press.

Kluge, A. G. \& Farris, J. S. (1969). Quantitative phyletics and the evolution of anurans. Syst Zool 18, 1-32.

Kudo, T., Itoh, T., Miyadoh, S., Shomura, T. \& Seino, A. (1993). Herbidospora gen. nov., a new genus of the family Streptosporangiaceae Goodfellow et al. 1990. Int J Syst Bacteriol 43, 319-328.

Kumar, S., Tamura, K., Jakobsen, I. B. \& Nei, M. (2001). MEGA2: molecular evolutionary genetics analysis software. Bioinformatics 17, $1244-1245$.

Lechevalier, M. P., De Bièvre, C. \& Lechevalier, H. A. (1977). Chemotaxonomy of aerobic actinomycetes: phospholipid composition. Biochem Syst Ecol 5, 249-260.
Minnikin, D. E., Alshamaony, L. \& Goodfellow, M. (1975). Differentiation of Mycobacterium, Nocardia, and related taxa by thin layer chromatographic analysis of whole-cell methanolysates. J Gen Microbiol 88, 200-204.

Minnikin, D. E., O'Donnell, A. G., Goodfellow, M., Alderson, G., Athalye, M., Schaal, A. \& Parlett, J. H. (1984). An integrated procedure for the extraction of bacterial isoprenoid quinones and polar lipids. J Microbiol Methods 2, 233-241.

Nakajima, Y., Kitpreechavanich, V., Suzuki, K. \& Kudo, T. (1999). Microbispora coralline sp. nov., a new species of the genus Microbispora isolated from Thai soil. Int J Syst Bacteriol 49, 17611767.

Saitou, N. \& Nei, M. (1987). The neighbor-joining method: a new method for reconstructing phylogenetic trees. Mol Biol Evol 4, 406425.

Shirling, E. B. \& Gottlieb, D. (1966). Methods for characterization of Streptomyces species. Int J Syst Bacteriol 16, 313-340.

Tamaoka, J. \& Komagata, K. (1984). Determination of DNA base composition by reversed-phase high-performance liquid chromatography. FEMS Microbiol Lett 25, 125-128.

Thompson, J. D., Gibson, T. J., Plewniak, F., Jeanmougin, F. \& Higgins, D. G. (1997). The CLUSTAL_X windows interface: flexible strategies for multiple sequence alignment aided by quality analysis tools. Nucleic Acids Res 25, 4876-4882.

Wayne, L. G., Brenner, D. J., Colwell, R. R., Grimont, P. A. D., Kandler, O., Krichevsky, M. I., Moore, L. H., Moore, W. E. C., Murray, R. G. E. \& other authors (1987). International Committee on Systematic Bacteriology. Report of the ad hoc committee on reconciliation of approaches to bacterial systematics. Int J Syst Bacteriol 37, 463464. 